\title{
Chemical Composition and Antioxidant Activity of Bunchosia glandulifera Fruit at Different Ripening Stages
}

\author{
Daiane Einhardt Blank*, Danize Justen, Sara Fraga, Carlos Roberto Peixoto, \\ Neusa Fernandes de Moura
}

Natural Products Research Group, Federal University of Rio Grande, Santo Antônio da Patrulha, Brazil

Email:*daiane_blank@yahoo.com.br

How to cite this paper: Blank, D.E., Justen, D., Fraga, S., Peixoto, C.R. and Moura, N.F. (2018) Chemical Composition and Antioxidant Activity of Bunchosia glandulifera Fruit at Different Ripening Stages. Food and Nutrition Sciences, 9, 1147-1159. https://doi.org/10.4236/fns.2018.910083

Received: September 9, 2018

Accepted: October 7, 2018

Published: October 11, 2018

Copyright $\odot 2018$ by authors and Scientific Research Publishing Inc. This work is licensed under the Creative Commons Attribution International License (CC BY 4.0).

http://creativecommons.org/licenses/by/4.0/

\begin{abstract}
Bunchosia glandulifera belongs to the family Malpighiaceae and is popularly known as "caferana" in the city of Santo Antonio da Patrulha. The fruits have a high economic value and their inclusion in the diet has health benefits. They are natural sources of antioxidants because of the presence of bioactive compounds. However, their chemical composition can be influenced by the maturation process. This study aims to evaluate the changes in the bioactive antioxidant compounds in the pulp and seeds of $B$. glandulifera fruit during different stages of ripening. The fruits, were analyzed for caffeine, carotenoids, flavonoids, vitamin $\mathrm{C}$, and total phenolic content as well as for antioxidant activity, at four different stages of ripening. An increase in bioactive compounds was observed from the second maturation stage to the ripened fruit, and the ripened fruit had the highest bioactive compound content. Phenolic compound and carotenoid levels were found to be highest in the pulp. Carotenoid content showed a positive correlation with the antioxidant activity. Colorimetric analysis also showed a high correlation between the levels of carotenoids and color change during the ripening stages.
\end{abstract}

\section{Keywords}

Bunchosia glandulifera, Ripening Stages, Caffeine, Carotenoids, Flavonoids, Antioxidant Activity, Vitamin C, Phenolic Content

\section{Introduction}

Bunchosia is one of the three genera belonging to the family Malpighiaceae. The plants are arborescent with fleshy fruits and are usually dispersed by birds [1]. 
The species glandulifera is one of the most cultivated plants of this genus, especially on small farms. In the city of Santo Antonio da Patrulha it is known as "false-guarana," and the toasted seed of the fruit is consumed [2].

The fruit is harvested for consumption when it is ripe and displays a red coloration. However, before ripening, the epicarp goes through three other coloring stages: green, yellow, and orange. The fruit ripens in approximately 30 days, and the last two ripening stages occur in a period of 3 to 4 days [3]. The fruit, in addition to providing nutrients to the body, also contains bioactive compounds that can provide protection against oxidative stress mediated diseases. This is one of the reasons why the consumption of this fruit has increased in recent years [4].

B. glandulifera contains high amounts of phenolic compounds, carotenoids, vitamin $\mathrm{C}$, and caffeine. Various phenolic acids and flavonoids such as gallic acid, syringic acid, rutin, quercetin, quercitrin, and trans cinnamic acid have been identified in B. glandulifera pulp by high performance liquid chromatography (HPLC) technique [2]. In relation to the antioxidant capacity, the pulp exhibited the highest antioxidant activity as compared with the seed. The antioxidant activity was assessed by several methods including 2,2'-diphenyl-1-picrylhydrazyl $(\mathrm{DPPH})$, ferric reducing antioxidant power (FRAP) and the 2,2'-azino-bis (3-ethylbenzothiazolin) 6-sulphonic acid (ABTS) method [2].

B. glandulifera is a sweet, high-protein fruit, and serves as a valuable source of essential minerals for the human diet. Blank et al. [5] have reported the presence of potassium, phosphorus, magnesium, silicon, calcium, zinc, and iron in $B$. glandulifera using the particle-induced X-ray emission (PIXE) technique.

The functional potential of $B$. glandulifera was also related to the presence of fatty acids, who have performed various physiological functions in the human organism. Chromatographic analysis for the presence of fatty acids in the pulp and seeds of B. glandulifera was carried out by the Bligh and Dyer method. The analysis showed the presence of 13 fatty acids in the pulp of the total $95.24 \%$ and 9 fatty acids of the total $97.09 \%$. Additionally, the pulp exhibited higher amount of saturated fatty acids, whereas the seed had a higher concentration of polyunsaturated fatty acids [5].

Among the bioactive compounds present in the fruit of B. glandulifera, the carotenoids and phenolic compounds are responsible for the color and antioxidant property, respectively [6]. Caffeine is a bioactive compound present in the seed of different fruit species and acts as a stimulator of the central nervous system [7].

Several physiological and metabolic factors play a role in changing the characteristics of fruits during the ripening process [3]. During this process the physical (color and texture) and chemical (flavor) characteristics can be monitored to ensure that the fruit is picked at the right time [4].

B. glandulifera is characterized as a climacteric fruit, that is, during the ripening period an increase in cellular respiratory activity is observed. Fruits with this characteristic exhibit a change in the concentration of bioactive compounds 
during the ripening process [8]. The objective of this study was to evaluate changes in the physicochemical composition, bioactive compounds, and antioxidant activity of the pulp and seeds of B. glandulifera during the different ripening stages.

\section{Material and Methods}

\subsection{Fruit Collection}

The fruits were collected in the city of Santo Antônio da Patrulha, RS, Brazil, during the summer period. Fruits at four stages of ripening were collected in January 2017:

- First stage: Fruits with a diameter of $2 \mathrm{~cm}$ and that were green in color were collected.

- Second stage: These fruits were collected 12 days after the first stage and were yellow-orange in color.

- Third stage: These fruits were collected 9 days after the second stage and were orange in color.

- Fourth stage: These fruits were collected 6 days after the third stage and were red in color.

After collection, the pulp was separated from the seed and frozen at $-18^{\circ} \mathrm{C}$ until further analysis.

\subsection{Physicochemical Analysis}

Physicochemical analysis of the fruit pulp was performed according to methodology described by the Adolfo Lutz Institute [9]. The $\mathrm{pH}$ was measured using a potentiometer with a glass electrode. Total acidity (TA) was calculated by titration of the filtrate (1:5 dilution) with $0.1 \mathrm{~N} \mathrm{NaOH}$, and the results were expressed in mg of citric acid/100 g. The soluble solids content (SS) was estimated using a refractometer (model ATAGO PR-101) and the results were expressed in ${ }^{\circ}$ Brix. Moisture content was determined by gravimetric analysis after oven drying at $105^{\circ} \mathrm{C}$. Lipid content was measured by gravimetric analysis after hexane extraction using Soxhlet apparatus. The method used for protein determination was the Kjeldahl digestion technique, whereas for ash content, gravimetry after incineration of the sample in muffle furnace was used. The fiber content was extracted using a Soxhlet apparatus. The residue was added to an acidic solution containing glacial acetic acid, nitric acid, and trichloroacetic acid, and refluxed. The obtained residue was heated in an oven at $105^{\circ} \mathrm{C}$ and incinerated at $550^{\circ} \mathrm{C}$. The reducing and total sugars were determined using Fehling reagent.

\subsection{Quantitation of Total Phenolics}

For the preparation of the extract, $1 \mathrm{~g}$ of pulp or seed and methanol, ethanol and acetone in the proportions of $45 \%, 45 \%$ and $10 \%$ respectively, were weighed for 20 minutes. Total phenolics were estimated according to the AOAC method 9110 [10] using the Folin-Denis reagent (Merck) and gallic acid as a standard. 
The results were expressed as mg GAE (gallic acid equivalent)/100 g.

\subsection{Quantitation of Total Carotenoids}

Total carotenoids of each ripening stage ( $0.5 \mathrm{~g}$ of freeze dried pulp) were extracted in $10 \mathrm{~mL}$ of hexane-acetone (6:4) extraction solution. The extracts were then stirred in tube shaker for $1 \mathrm{~min}$ and left stagnant for $9 \mathrm{~min}$. The extracts were then filtered through cotton and the absorption (in triplicates) of the resultant filtrate was measured at $450 \mathrm{~nm}$ and $470 \mathrm{~nm}$ for lycopene as well as $\beta$-carotene, using a spectrophotometer. $\beta$-carotene and lycopene were used as standards to construct the calibration curve. The total carotenoid content was determined by Equation (1), and the results, in dry basis, were expressed as $\mathrm{mg}$ of $\beta$-carotene $/ 100 \mathrm{~g}$ of sample [11].

$$
C=\frac{A B S \times 50 \mathrm{~mL} \times 1000000}{2500 \times 100 \times \mathrm{g} \text { sample }}
$$

where $C=$ carotenoid content of the sample and $A B S=$ absorbance.

\subsection{Quantitation of Total Flavonoids}

A $0.5 \mathrm{~mL}$ aliquot of fruit extract was added to $1 \mathrm{~mL}$ of water and $0.3 \mathrm{~mL}$ of $5 \%$ sodium nitrite. After $5 \mathrm{~min}, 10 \%$ aluminum chloride $(0.3 \mathrm{~mL})$ was added, followed by addition of $2 \mathrm{~mL}$ of $1 \mathrm{M}$ sodium hydroxide after $1 \mathrm{~min}$. The samples were mixed using an ultrasonicator and the final volume was made up to $10 \mathrm{~mL}$ with water. The resulting samples were measured at $510 \mathrm{~nm}$ using a spectrophotometer. The calibration curve was obtained using quercetin as the standard, and the results were expressed as mg quercetin / $100 \mathrm{~g}$ of sample.

\subsection{Antioxidant Activity}

The antioxidant activity of fruit pulp was determined using the DPPH radical, according to the protocol described by Brand-Williams et al. [12] with some modifications. A solution of $0.06 \mathrm{mM} \mathrm{DPPH}$ was prepared in $100 \mathrm{~mL}$ of methanol. Fruit pulp extract $(100 \mu \mathrm{L})$ was added to $3.9 \mathrm{~mL}$ of DPPH solution. The decrease in the absorbance was monitored at $517 \mathrm{~nm}$. The results were expressed as $\%$ antioxidant activity.

\subsection{Vitamin C Content}

The ascorbic acid in the fruit pulp was determined by 2,6-dichloroindophenol using a tritrimetric method. Juice pulp in $100 \mathrm{~mL}$ of distilled water was titrated with previously prepared $20 \mathrm{~mL}$ aliquot of standardized dichloroindophenol solution [13]. Vitamin C content was expressed as mg ascorbic acid/100 $\mathrm{g}$ of sample.

\subsection{Caffeine Content}

Caffeine content was estimated by a simple method consisting of an acid extraction, by selective carbonization of organic matter in the sample with sulfuric acid to release caffeine, followed by extraction with chloroform. The extracted caffe- 
ine was quantitated by measuring its absorbance at $274 \mathrm{~nm}$ using a spectrophotometer IAL [9] and expressed as mg caffeine/100 $\mathrm{g}$ of sample.

\subsection{Colorimetric Analysis}

The color of the fruit at different stages of maturation was determined by reflectometry in accordance to the CIE system (Commission Internacionale de L'Eclaraige) using the portable colorimeter (CR-410, Konica Minolta) through the surface contact of the colorimeter with the fruit at different stages of maturation. The calibration was performed on white porcelain surface under lighting conditions. The readings were expressed in modules $L^{*}$ which represents the brightness, and varies from 0 to 100 , with zero being the total black and 100 the total white, $\mathrm{a}^{\star}$ representing the intensity of the red color, the chromaticity axis of green $(-)$ to red $(+)$ and $b^{*}$ which represents the chromaticity axis of blue $(-)$ to yellow $(+)$. In addition to these color coordinates, the color parameters were also read as the chroma value $C^{\star}=\left(a^{\star} 2+b^{\star} 2\right) 1 / 2$, representing color purity, and angle measurement $h^{*}=\operatorname{tg}-1\left(b^{\star} / a^{*}\right)$, which represents the color tint [14] [15].

\subsection{Statistical Analysis}

The analysis was performed using the SPSS Statistics $24.0^{\circledR}$ program. Data were expressed as mean \pm standard deviation of triplicate determinations. The differences between the samples were analyzed by Student's $t$-test $(\mathrm{p}<0.05)$. Relationship between the bioactive compounds and antioxidant activity were studied using Pearson's correlation.

\section{Results and Discussion}

Fruits of $B$. glandulifera when ripened present red coloration. However, before ripening the fruit undergoes three stages with different colors (green, yellow/orange and orange). Analyzing the chemical composition of the fruit (pulp and seed) during the different ripening stages can be beneficial for better utilization of the fruit.

Phytochemical composition including total phenolics, flavonoids, lycopene, $\beta$-carotene, caffeine, vitamin $\mathrm{C}$, and antioxidant activity of the pulp and the seed of $B$. glandulifera are presented in Table 1 and Table 2, respectively.

As can be seen in Table 1 and Table 2, concentration of the bioactive compounds and antioxidant activity increased throughout the ripening stage of the fruit (pulp and seed). The ripening process from green to red in B. glandulifera, a seasonal fruit, occurred in a period of 27 days. During this period, concentration of carotenoids in the pulp, especially that of lycopene increased drastically. It is known that the change in coloration occurs by degradation of chlorophyll and synthesis of carotenoids [16]. It was observed that the $\beta$-carotene concentration was higher during the first two stages of maturation, whereas from the third stage (orange), concentration of lycopene was increased. Lima et al. [17], have 
Table 1. Phytochemical composition and antioxidant activity of $B$. glandulifera pulp during different ripening stages.

\begin{tabular}{ccccc}
\hline Parameters & Green & Yellow/orange & Orange & Red \\
\hline $\begin{array}{c}\text { Total phenolics } \\
(\mathrm{mg} \text { GAE} / 100 \mathrm{~g})\end{array}$ & $698.82^{\mathrm{a}, \mathrm{b}} \pm 3.81$ & $728.53^{\mathrm{a}, \mathrm{b}} \pm 2.87$ & $804.68^{\mathrm{a}, \mathrm{b}} \pm 4.11$ & $1692.35^{\mathrm{c}} \pm 33.17$ \\
$\begin{array}{c}\text { Flavonoids } \\
(\mathrm{mg} \text { quercetin/100 g) }\end{array}$ & $206.95^{\mathrm{a}} \pm 18.28$ & $260.22^{\mathrm{a}} \pm 13.20$ & $329.01^{\mathrm{b}, \mathrm{d}} \pm 24.14$ & $406.69^{\mathrm{c}, \mathrm{d}} \pm 16.25$ \\
Caffeine (mg/100 g) & $117.65^{\mathrm{a}} \pm 9.33$ & $189.22^{\mathrm{b}} \pm 13.14$ & $206.80^{\mathrm{b}} \pm 15.05$ & $375.81^{\mathrm{c}} \pm 38.79$ \\
Vitamin C (mg/100 g) & $24.09^{\mathrm{a}} \pm 1.07$ & $25.92^{\mathrm{a}} \pm 1.52$ & $29.41^{\mathrm{b}} \pm 0.23$ & $31.25^{\mathrm{b}} \pm 0.40$ \\
$\beta$-carotene (mg/100 g) & $0.69^{\mathrm{a}} \pm 0.03$ & $1.39^{\mathrm{b}} \pm 0.02$ & $5.07^{\mathrm{c}} \pm 0.09$ & $6.75^{\mathrm{d}} \pm 0.17$ \\
Lycopene (mg/100 g) & $0.25^{\mathrm{a}} \pm 0.01$ & $0.75^{\mathrm{b}} \pm 0.02$ & $6.74^{\mathrm{c}} \pm 0.17$ & $10.29^{\mathrm{d}} \pm 0.09$ \\
Antioxidantactivity (\%) & $8.02^{\mathrm{a}} \pm 0.36$ & $8.18^{\mathrm{a}} \pm 0.05$ & $8.57^{\mathrm{a}} \pm 0.59$ & $13.24^{\mathrm{b}} \pm 0.66$ \\
\hline a,b,c,d,e Dissimilar alphabets on the same line indicate significant difference between samples $(\mathrm{p}<0.05)$. Re- \\
sults are presented as mean \pm standard derivation.
\end{tabular}

Table 2. Phytochemical composition and antioxidant activity of $B$. glandulifera seed during different ripening stages.

\begin{tabular}{|c|c|c|c|c|}
\hline Parameters & Green & Yellow/orange & Orange & Red \\
\hline $\begin{array}{l}\text { Total phenolics } \\
\text { (mg GAE/100 g) }\end{array}$ & $224.97^{\mathrm{a}, \mathrm{b}} \pm 12.51$ & $268.73^{\mathrm{a}, \mathrm{b}, \mathrm{c}, \mathrm{e}} \pm 17.15$ & $280.32^{\mathrm{b}, \mathrm{c}, \mathrm{d}, \mathrm{e}} \pm 24.26$ & $333.93^{\mathrm{d}, \mathrm{e}} \pm 13.72$ \\
\hline $\begin{array}{c}\text { Flavonoids } \\
\text { (mg quercetin } / 100 \mathrm{~g})\end{array}$ & $63.46^{\mathrm{a}, \mathrm{b}} \pm 5.06$ & $73.24^{\mathrm{a}, \mathrm{b}, \mathrm{c}, \mathrm{e}} \pm 4.89$ & $85.65^{\mathrm{b}, \mathrm{c}, \mathrm{d}, \mathrm{e}} \pm 8.37$ & $98.34^{\mathrm{c}, \mathrm{d}, \mathrm{e}} \pm 6.28$ \\
\hline Caffeine $(\mathrm{mg} / 100 \mathrm{~g})$ & $298.23^{\mathrm{a}, \mathrm{b}} \pm 9.89$ & $342.81^{\mathrm{a}, \mathrm{b}} \pm 17.89$ & $413.47^{\mathrm{b}} \pm 23.83$ & $820.73^{\mathrm{c}} \pm 12.90$ \\
\hline Vitamin C $(\mathrm{mg} / 100 \mathrm{~g})$ & $13.15^{\mathrm{a}} \pm 0.13$ & $14.56^{\mathrm{a}} \pm 0.09$ & $17.73^{b} \pm 0.08$ & $17.98^{\mathrm{b}} \pm 0.11$ \\
\hline$\beta$-carotene $(\mathrm{mg} / 100 \mathrm{~g})$ & $0.59^{\mathrm{a}} \pm 0.01$ & $0.69^{b, c} \pm 0.04$ & $0.77^{\mathrm{b}, c, \mathrm{~d}} \pm 0.06$ & $0.93^{\mathrm{c,d}} \pm 0.01$ \\
\hline Antioxidant activity (\%) & $5.99^{\mathrm{a}} \pm 0.50$ & $6.23^{\mathrm{a}} \pm 0.22$ & $6.57^{\mathrm{a}} \pm 0.37$ & $7.65^{\mathrm{b}} \pm 0.64$ \\
\hline
\end{tabular}

analyzed the concentration of $\beta$-carotene in acerola at three ripening stages, and have reported that the concentration of this compound was 1.0 to $3.52 \mu \mathrm{g} / \mathrm{g}$ in green, 1.40 to $5.89 \mu \mathrm{g} / \mathrm{g}$ in half-mature, and 16.90 to $40.6 \mu \mathrm{g} / \mathrm{g}$ in the mature stage. This result indicates that the synthesis of carotenoids continue until the end of ripening, thus corroborating with the results of the present study. The seed had a low concentration of carotenoids during the ripening stages, and lycopene was not been identified during the ripening process. The seed is used by the local population as a stimulant property, and this activity is associated with the presence of caffeine in the fruit [2]. In the seeds, caffeine was the bioactive compound with the highest increase in its amount during the ripening process.

During the initial stage of ripening, the amount of vitamin C increased gradually, whereas from the third stage of maturation a significant increase in its concentration was observed. In red-Murici, an increase in vitamin $\mathrm{C}$ concentration during the ripening process was observed. Additionally, it was also reported that the biosynthesis of vitamin C increases with the development of the fruit [18]. In 
addition, the results of this study agree with the data obtained from other fruits, such as grapes and strawberry, in which vitamin C levels were shown to increase during the development of these fruits [19].

Significant increase in the amount of phenolic compounds was observed only in the fourth ripening stage of the pulp. The pulp presented higher concentration of phenolic compounds than the seed. Similar increase in the concentration of flavonoids was observed. Fu et al. [20] have reported that the color change from green to yellow may be related to carotenoid synthesis and the presence of flavonoids.

Fruits of B. glandulifera in the mature stage showed significant levels of bioactive compounds such as carotenoids, total phenolics, flavonoids, and vitamin C, thus making this fruit a promising source of antioxidant compounds. To understand the effect of these phytochemical constituents on antioxidant capacity in this fruit during the ripening process, a correlation analysis between the antioxidant activity and the bioactive compounds (phenolic compounds, flavonoids, vitamin C, $\beta$-carotene, lycopene) was carried out (Table 3 ).

As can be seen in Table 3, a positive correlation between the examined bioactive compounds of the fruit pulp and antioxidant activity was obtained. Vitamin $\mathrm{C}$ content and antioxidant activity $(\mathrm{r}=0.79)$ show a moderate correlation. Meanwhile, the correlation between phenolic compounds and antioxidant activity ( $\mathrm{r}=0.99)$ was considered to be very strong $(0.8<\mathrm{r}<1)$, according to Pearson's correlation. Being a positive coefficient, we can say that higher the phenolic concentration, the greater is the antioxidant activity. Therefore, this indicates that phenolic compounds contribute significantly to antioxidant capacity during the ripening process. Several studies have correlated the presence of phenolic compounds in the fruits with the antioxidant activity. Lima et al. [21] reported a strong correlation between phenolic compounds and antioxidant activity. In a study analyzing bioactive compounds from tropical fruits, a correlation coefficient of 0.70 between vitamin $\mathrm{C}$ content and antioxidant activity was considered as a moderate correlation, whereas with phenolic compounds $r=0.92$, was considered a strong correlation [22]. Almeida et al. [23] also found positive correlations between phenolic compounds and antioxidant activity in exotic fruits. Although positive correlations were observed between the bioactive compounds and antioxidant activity, it should be noted that the antioxidant activity may be related to the synergism of the bioactive compounds present in the B. glandulifera pulp. The physicochemical composition observed during the four stages of maturation in pulp and seeds are shown in Table 4 and Table 5, respectively.

During ripening, no significant increase in moisture, protein, lipids, and ash content in B. glandulifera pulp was observed, whereas in the seeds only the moisture and lipid content did not show significant increase. The $\mathrm{pH}$ value decreased during ripening in both the pulp and seeds. The titratable acidity values increased during ripening. When climacteric fruits approach maturity, there is an increase in respiratory rate, synthesis of hormones and precursors of ethylene, degradation of the cell wall, and synthesis of sugars from the reserves. 
Table 3. Pearson's correlation coefficient ( $\mathrm{r}$ ) between the bioactive compounds and antioxidant activity of $B$. glandulifera fruit pulp extract during the ripening stages.

\begin{tabular}{cc}
\hline Variable & ${\text { Correlation coefficient }(\mathrm{r})^{*}}^{*}$ Phenolic Compounds \\
Flavonoids & 0.99 \\
Vitamin C & 0.86 \\
$\beta$-carotene & 0.79 \\
Lycopene & 0.83 \\
\hline
\end{tabular}

${ }^{*}$ Pearson's correlation.

Table 4. Physicochemical composition of B. glandulifera pulp during the ripening stages.

\begin{tabular}{ccccc}
\hline Parameters & Green & Yellow/orange & Orange & Red \\
\hline Moisture & $72.94^{\mathrm{a}} \pm 0.85$ & $72.91^{\mathrm{a}} \pm 0.10$ & $72.72^{\mathrm{a}} \pm 0.34$ & $72.69^{\mathrm{a}} \pm 0.71$ \\
pH & $7.60^{\mathrm{a}} \pm 0.11$ & $6.53^{\mathrm{b}} \pm 0.12$ & $5.78^{\mathrm{c}} \pm 0.11$ & $5.36^{\mathrm{c}} \pm 0.18$ \\
Titratable Acidity & $2.98^{\mathrm{a}} \pm 0.543$ & $3.39^{\mathrm{b}} \pm 0.11$ & $3.61^{\mathrm{b}} \pm 0.25$ & $3.88^{\mathrm{b}} \pm 0.29$ \\
Fiber & $1.39^{\mathrm{a}} \pm 0.01$ & $1.37^{\mathrm{a}} \pm 0.04$ & $0.98^{\mathrm{b}} \pm 0.03$ & $0.64^{\mathrm{c}} \pm 0.01$ \\
Proteins & $2.69^{\mathrm{a}} \pm 0.15$ & $2.65^{\mathrm{a}} \pm 0.17$ & $2.58^{\mathrm{a}} \pm 0.12$ & $2.53^{\mathrm{b}} \pm 0.21$ \\
Soluble Solids & $8.98^{\mathrm{a}} \pm 0.03$ & $9.64^{\mathrm{b}} \pm 0.05$ & $11.09^{\mathrm{c}} \pm 0.09$ & $12.59^{\mathrm{d}} \pm 0.11$ \\
Total Sugars & $4.80^{\mathrm{a}} \pm 0.22$ & $5.20^{\mathrm{a}} \pm 0.03$ & $5.95^{\mathrm{b}} \pm 0.06$ & $6.94^{\mathrm{c}} \pm 0.07$ \\
Reducing sugars & $2.50^{\mathrm{a}} \pm 0.07$ & $2.86^{\mathrm{a}} \pm 0.03$ & $3.12^{\mathrm{a}} \pm 0.4$ & $3.85^{\mathrm{b}} \pm 0.043$ \\
Lipids & $0.11^{\mathrm{a}} \pm 0.07$ & $0.14^{\mathrm{a}} \pm 0.13$ & $0.19^{\mathrm{a}} \pm 0.29$ & $0.24^{\mathrm{a}} \pm 0.08$ \\
Ashes & $1.20^{\mathrm{a}} \pm 0.05$ & $1.30^{\mathrm{a}} \pm 0.05$ & $1.60^{\mathrm{a}} \pm 0.06$ & $1.80^{\mathrm{a}} \pm 0.19$ \\
\hline
\end{tabular}

${ }^{\mathrm{a}, \mathrm{b}, \mathrm{c}}$ Dissimilar alphabets on the same line indicate significant difference between samples $(\mathrm{p}<0.05)$. Results are presented as mean \pm standard derivation.

Table 5. Physicochemical composition of B. glandulifera seeds during the ripening stages.

\begin{tabular}{ccccc}
\hline Parameters & Green & Yellow/orange & Orange & Red \\
\hline Moisture & $56.78^{\mathrm{a}} \pm 0.42$ & $56.69^{\mathrm{a}} \pm 0.45$ & $56.04^{\mathrm{a}} \pm 0.16$ & $55.64^{\mathrm{a}} \pm 0.45$ \\
pH & $9.09^{\mathrm{a}} \pm 0.04$ & $8.54^{\mathrm{b}} \pm 0.05$ & $8.35^{\mathrm{b}} \pm 0.04$ & $8.24^{\mathrm{bc}} \pm 0.03$ \\
Titratable Acidity & $1.76^{\mathrm{a}} \pm 0.24$ & $2.09^{\mathrm{b}} \pm 0.28$ & $2.16^{\mathrm{b}} \pm 0.22$ & $2.26^{\mathrm{b}} \pm 0.18$ \\
Fiber & $2.69^{\mathrm{a}} \pm 0.12$ & $2.14^{\mathrm{b}} \pm 0.19$ & $2.06^{\mathrm{b}} \pm 0.20$ & $1.98^{\mathrm{b}} \pm 0.20$ \\
Proteins & $7.69^{\mathrm{a}} \pm 0.22$ & $7.5^{\mathrm{a}} \pm 0.27$ & $7.29^{\mathrm{b}} \pm 0.21$ & $6.87^{\mathrm{c}} \pm 0.18$ \\
Soluble Solids & $2.08^{\mathrm{a}} \pm 0.02$ & $3.27^{\mathrm{b}} \pm 0.03$ & $3.81^{\mathrm{b}} \pm 0.02$ & $4.74^{\mathrm{c}} \pm 0.04$ \\
Total Sugars & $1.08^{\mathrm{a}} \pm 0.20$ & $1.66^{\mathrm{ab}} \pm 0.05$ & $1.97^{\mathrm{b}} \pm 0.08$ & $2.06^{\mathrm{b}} \pm 0.02$ \\
Lipids & $0.27^{\mathrm{a}} \pm 0.04$ & $0.31^{\mathrm{a}} \pm 0.04$ & $0.38^{\mathrm{a}} \pm 0.05$ & $0.47^{\mathrm{a}} \pm 0.04$ \\
Ashes & $2.02^{\mathrm{a}} \pm 0.10$ & $2.08^{\mathrm{a}} \pm 0.12$ & $2.39^{\mathrm{ab}} \pm 0.09$ & $2.7^{\mathrm{b}} \pm 0.01$ \\
\hline
\end{tabular}

a,b,c Dissimilar alphabets on the same line indicate significant difference between samples $(\mathrm{p}<0.05)$. Results are presented as mean \pm standard derivation. 
During this period, the organic acids are used as energy source accelerating the ripening stages of the fruit; the $\mathrm{pH}$ decreases as a result of its use as a substrate in the respiratory process or conversion to sugars and, consequently, increases the acidity [23].

The fiber contents in the seed decreased from the second stage of the ripening process in B. glandulifera. The fiber content in the pulp decreased only in the third stage of maturation and the reduction continued until the fourth stage. This decrease in fiber content may be related to the degradation of cell wall components, or depolymerization of pectins, cellulose, and hemicellulose [25]. The content of sugars and soluble solids showed an increase in concentration during the fruit ripening process, similar to the result observed in Byrsonima ligustrifolia, a species belonging to the same family [18]. The pulp exhibited significant difference in the content of soluble solids during the four ripening stages. This increase is related to the sugar content and may represent an indirect measure of the sugar contents in the fruit, making them more attractive to the consumer. There is a correlation between consumer acceptance and ${ }^{\circ}$ Brix and acidity parameters, and these usually represent maturation indicators [26].

The increase in lipid and ash contents in the pulp and seed during maturation analyzed is observed. It was observed that the lipid and ash content was higher in the seeds as compared with the fruit pulp. The result of the lipid content is expected, because the seeds have a reservoir of lipids. In a study on the fatty acid profile of B. glandulifera, a high percentage of fatty acids was observed in the pulp and seed, wherein the seed had a higher amount of polyunsaturated fatty acids [5]. The ash content corresponds to the amount of mineral substances present in foods [27]. B. glandulifera is a valuable source of essential minerals for the human diet, as both in the pulp and seed major minerals were observed, and the seed had a higher mineral content [5].

The chromatic characteristics of pulp and seeds of B. glandulifera during the maturation stages are presented in Table 6 and Table 7, respectively. Differences were observed in $L^{*}$, chromaticity and angle between maturation stages.

At the last stage of maturation, the pulp of B. glandulifera exhibited the lowest values of $\mathrm{L}^{*}$, chroma $\left(\mathrm{b}^{*}\right)$ and Angle $\left(\mathrm{h}^{*}\right)$. The loss of luminosity is verified by the reduction of the value of $L^{*}$, since it represents the photometric parameter proportional to the light reflected by the object. Negative value of $a^{\star}$ indicates green tint and, positive value indicates a red tint. As the maturation stage of $B$. glandulifera advanced, the values of $\mathrm{a}^{*}$ changed to red-orange and consequently the carotenoid content also increased. Similar results were observed by Vendramini and Trugo [28], while analyzing the $\mathrm{a}^{*}$ values in the three maturation stages of acerola. The degradation of the chlorophyll present in the chloroplasts of the plant cell and the biosynthesis of anthocyanins throughout the fruit ripening process led to an increase in the value of the parameter $\mathrm{a}^{\star}$ [29]. The values of " $b$ *" were higher in the green fruits, reducing along their development, showing the slight presence of the yellow tonality. The ripe fruits presented pulp with predominantly red coloration, as determined by the hue angle $\left(h^{*}\right)$, with a grade 
of 26.07. The tonalities of the fruit in the green, yellow and orange stage were $70.05,54.97$, and 36.27 respectively. These stages of maturation would correspond to the minimum and maximum limits on a scale ranging from green (stage 1), intermediate I (stage 2), intermediate II (stage 3) and mature (stage 4). Table 8 presents Pearson's correlation between the variables: $\beta$-carotene, lycopene of the pulp with chromaticity.

The analysis of correlation highlights a positive correlation between $\beta$-carotene and lycopene content and chromaticity, with a value close to 1 , and

Table 6. Colorimetric parameters of Bunchosia glandulifera pulp during different stages of ripening.

\begin{tabular}{ccccc}
\hline Parameters & Green & Yellow/orange & Orange & Red \\
\hline $\mathrm{a}^{*}$ & -13.15 & 16.55 & 33.86 & 40.66 \\
$\mathrm{~b}^{*}$ & 36.23 & 23.61 & 24.85 & 19.90 \\
$\mathrm{~L}^{*}$ & 42.94 & 36.47 & 37.25 & 31.74 \\
$\mathrm{C}^{*}$ & 38.54 & 28.83 & 42.00 & 45.52 \\
$\mathrm{~h}^{*}$ & 70.05 & 54.97 & 36.27 & 26.07 \\
\hline
\end{tabular}

$\mathrm{a}^{*}$ : represents the chromaticity axis of green $(-)$ to red $(+) ; b^{*}$ : represents the chromaticity axis of blue $(-)$ to yellow $(+)$; $L^{*}$ : brightness index, $C^{*}$ : chroma value, representing color purity; $h^{\star}$ : angle measurement: representing the color tint.

Table 7. Colorimetric parameters of Bunchosia glandulifera seed during different stages of ripening.

\begin{tabular}{ccccc}
\hline Parameters & Green & Yellow/orange & Orange & Red \\
\hline $\mathrm{a}^{*}$ & -15.27 & -13.68 & -15.59 & -5.80 \\
$\mathrm{~b}^{*}$ & 38.25 & 32.03 & 35.42 & 27.64 \\
$\mathrm{~L}^{*}$ & 54.09 & 41.79 & 48.34 & 55.07 \\
$\mathrm{C}^{*}$ & 41.18 & 34.82 & 38.69 & 28.24 \\
$\mathrm{~h}^{*}$ & 68.23 & 66.87 & 66.24 & 78.14 \\
\hline
\end{tabular}

$\mathrm{a}^{*}$ : represents the chromaticity axis of green $(-)$ to red $(+) ; b^{*}$ : represents the chromaticity axis of blue (-) to yellow $(+)$; $\mathrm{L}^{*}$ : brightness index, $\mathrm{C}^{*}$ : chroma value, representing color purity; $\mathrm{h}^{*}$ : angle measurement: representing the color tint.

Table 8. Pearson's correlation coefficient $(\mathrm{r})$ between the $\beta$-carotene, lycopene and chromaticity of $B$. glandulifera fruit pulp during the ripening stages.

\begin{tabular}{cccccc}
\hline & $\begin{array}{c}\beta \text {-carotene } \\
(\mathrm{mg} / 100 \mathrm{~g})\end{array}$ & $\begin{array}{c}\text { Lycopene } \\
(\mathrm{mg} / 100 \mathrm{~g})\end{array}$ & $\mathbf{a}^{*}$ & $\mathrm{~b}^{*}$ & $\mathrm{a}^{*} / \mathrm{b}^{*}$ \\
\hline Green & 0.69 & 0.25 & -13.15 & 0.25 & -0.36 \\
Yellow/orange & 1.39 & 0.75 & 16.55 & 0.75 & 0.70 \\
Orange & 5.07 & 6.74 & 33.86 & 6.74 & 1.36 \\
Red & 6.75 & 10.29 & 40.66 & 10.29 & 2.04 \\
Correlation coefficient $(\mathrm{r})^{*}$ & 0.94 & 0.92 & & &
\end{tabular}

$\mathrm{a}^{*}$ : represents the chromaticity axis of green $(-)$ to red $(+) ; b^{*}$ : represents the chromaticity axis of blue $(-)$ to yellow $(+) ;{ }^{*}$ correlation coefficient. 
hence indicates to be a strong correlation. Similar results were also found in a study correlating colorimetric values and carotenoids in sows [30]. In this study, the correlation of color changes with carotenoid content suggests that the more intense the color, greater is the content of these bioactive compounds.

\section{Conclusion}

B. glandulifera is a nutritious fruit that contains bioactive compounds with antioxidant potential. During the ripening stages of the fruit, a significant increase in the content of bioactive compounds was observed, with higher concentrations being found from the third stage. Higher variation was found for carotenoids, since they are responsible for the color of the fruit, which changes during the ripening process. The antioxidant activity only increased in the last stage of maturation and remained the same during the first three stages. Taken together, these results suggest that the fruit should be consumed when it is fully ripened (red in color), as, in this stage, the fruit has higher levels of nutrients and a higher content of bioactive compounds.

\section{Conflicts of Interest}

The authors declare no conflicts of interest regarding the publication of this paper.

\section{References}

[1] Anderson, W.R. (2017) http://herbarium.lsa.umich.edu/herb/malpigh

[2] Silva, S.F., Blank, D.E., Peixoto, C.R., Moreira, J.J.S. and Moura, N.F. (2016) Bioactive Compounds and Antioxidant Activity of Bunchosia glandulifera. International Journal of Food Properties, 19, 467-473.

[3] Perotti, V.E., Moreno, A.S. and Podestá, F.E. (2014) Physiological Aspects of Fruit Ripening: The Mitochondrial Connection. Mitochondrion, 17, 1-6.

[4] Tiwari, U. and Cummins, E. (2013) Factors Influencing Levels of Phytochemicals in Selected Fruit and Vegetables during Pre- and Post-Harvest Food Processing Operations. Food Research International, 50, 497-506. https://doi.org/10.1016/j.foodres.2011.09.007

[5] Blank, D.E., Fraga, S., Bellaver, M., Santos, C.E.I., Costa, L.A.M.A. and Moura, N.F. (2017) Proximate Composition, Nutrient Mineral and Fatty Acid of the Bunchosia glandulifera Fruit. Journal of Food and Nutrition Research, 5, 575-578.

[6] Park, K.J., Moreno, M.K. and Brod, F.P.R. (2006) Estudo de secagem de pêra Bartlett. Ciência e Tecnologia de Alimentos, 21, 288-292.

[7] Ho, S.C. and Chung, J.W. (2013) The Effects of Caffeine Abstinence on Sleep: A Pilot Study. Applied Nursing Research, 26, 80-84. https://doi.org/10.1016/j.apnr.2012.08.004

[8] Ummarat, N., Matsumoto, T.K., Wall, M.M. and Seraypheap, K. (2011) Changes in Antioxidants and Fruit Quality in Hot Water-Treated "Hom Thong" Banana Fruit during Storage. Scientia Horticulturae, 130, 801-807. https://doi.org/10.1016/j.scienta.2011.09.006

[9] IAL, Institute Adolfo Lutz (2008) Methods for Chemical and Physical Analysis of 
Food. 4th Edition, Analytical Standards of the Institute Adolfo Lutz, São Paulo.

[10] AOAC (1980) Official Methods of Analysis. 12th Edition, Association of Official Analytical Chemists, Washington.

[11] Rodriguez-Amaya, D.B. and Kimura, M. (2004) HarvestPlus Handbook for Carotenoid Analysis. HarvestPlus Technical Monograph: Washington, DC and Cali: International Food Policy Research Institute (IFPRI) and International Center for Tropical Agriculture (CIAT), 58.

[12] Brand-Williams, W., Cuvelier, M.E. and Berset, C. (1995) Use of Free Radical Method to Evaluate Antioxidant Activity. Lebensm Wiss Technology, 28, 25-30. https://doi.org/10.1016/S0023-6438(95)80008-5

[13] AOAC (2006) Official Methods of Analysis. 18th Edition, Association of Official Analytical Chemists, Washington.

[14] Mcguire, R.G. (1992) Reporting of Objective Color Measurements. HortScience, 27, 1254-1555.

[15] Konica Minolta, Konica MinoltaSensing, Inc. (1998) Precise Color Communication. Color Control from Perception to Instrumentation. Daisennishimachi, Sakai. Osaka, Japan, 59.

[16] Ayala-Zavala, J.F., Vega-Veja, V., Rosas-Domínguez, C., Palafox-Carlos, H., Villa-Rodriguez, M.D., Wasim Siddiqui, J.A., Dávila-Aviña, J.E. and González-Aguilar, G.A. (2011) Agro-Industrial Potential of Exotic Fruit Byproducts as a Source of Food Additives. Food Research International, 44, 1866-1874.

[17] Lima, V.L.A.G., et al. (2005) Total Phenolic and Carotenoid Contents in Acerola Genotypes Harvested at Three Ripening Stages. Food Chemistry, 90, 495-896.

[18] Sampaio, C.R.P., Hamerski, F. and Ribani, R.H. (2015) Antioxidant Phytochemicals of Byrsonima ligustrifolia throughout Fruit Developmental Stages. Journal of Functional Foods, 18, 400-410. https://doi.org/10.1016/j.jff.2015.08.004

[19] Cruz-Rus, E., Botella, M.A. and Gomez-Jimenez, M.C. (2010) Analysis of Genes Involved in L-Ascorbic Acid Biosynthesis during Growth and Ripening of Grape Berries. Journal of Plant Physiology, 167, 739-748.

[20] Fu, X., Cheng, S., Liao, Y., Huang, B., Du, B., Zeng, W., Jiang, Y., Duan, X. and Yang, Z. (2017) Comparative Analysis of Pigments in Red and Yellow Banana Fruit. Food Chemistry, 239, 1009-1018.

[21] Lima, C.P., Cunico, M.M., Miyazaki, C.M.S., Miguel, O.G., Côcco, L.C., Yamamoto, C.I. and Miguel, M.D. (2012) Polyphenolic Content and Antioxidant Capacity of Fruits of Juçara (Euterpe edulis Martius) Palmtree. Revista Brasileira de Plantas Medicinais, 14, 321-326.

[22] Rufino, M.S.M., Alves, R.E., Brito, E.S., Pérez-Jiménez, J., Saura-Calixto, F. and Mancini-Filho, J. (2010) Bioactive Compounds and Antioxidante Capacities of 18 Non-Traditional Tropical Fruits from Brazil. Food Chemistry, 121, 996-1002. https://doi.org/10.1016/j.foodchem.2010.01.037

[23] Almeida, M.M.B., Sousa, P.H.M., Arriaga, A.M.C., Prado, G.M., Magalhães, C.E.C., Maia, G.A. and Lemos, T.L.G. (2011) Bioactive Compounds and Antioxidante Activity of Fresh Exotic Fruits from Northe as Tern Brazil. Food Research International, 44, 2155-2159. https://doi.org/10.1016/j.foodres.2011.03.051

[24] Fawole, O.A. and Opara, U.L. (2013) Effects of Storage Temperature and Duration on Physiological Responses of Pomegranate Fruit. Industrial Crops and Products, 47, 300-309. https://doi.org/10.1016/j.indcrop.2013.03.028

[25] Kerbauy, G.B. (2012) Fisiologia Vegetal. 2nd Edition, Guanabara-Koogan, 431. 
[26] Jayasena, V. and Cameron, I. (2008) Brix/Acid Ratio as a Predictor of Consumer Acceptability of Crimson Seedless Table Grapes. Journal of Food Quality, 31, 736-750. https://doi.org/10.1111/j.1745-4557.2008.00231.x

[27] Chaves, M.C.V. (2004) Caracterização físico-quimica do suco da acerola. Revista de biologia e ciências da terra, 4.

[28] Vendramini, A.L. and Trugo, L.C. (2000) Chemical Composition of Acerola Fruit (Malpighia glabra L.) at Three Stages of Maturity. Food Chemistry, 71, 195-198. https://doi.org/10.1016/S0308-8146(00)00152-7

[29] Gonçalves, B. (2007) Effect of Ripeness and Postharvest Storage on the Evolution of Colour and Anthocyanins in Cherries (Prunus avium L.). Food Chemistry, 103, 976-984. https://doi.org/10.1016/j.foodchem.2006.08.039

[30] Pace, B., Cefola, M., Renna, F., Renna, M., Serio, F. and Attolico, G. (2013) Multiple Regression Model Sand Computer Vision Systems to Predict Antioxidant Activity and Total Phenols in Pigmented Carrots. Journal of Food Engineering, 117, 74-81. 